\title{
The effect of selected growth regulators and culture media on regeneration of Daphne mezereum L. 'Alba'
}

\author{
Karolina Nowakowska ${ }^{1} \cdot$ Andrzej Pacholczak ${ }^{1} \cdot$ Waldemar Tepper $^{1}$
}

Received: 28 August 2018 / Accepted: 21 January 2019 / Published online: 7 February 2019

(C) The Author(s) 2019

Key message Tissue cultures are the only effective way to proliferate this valuable species (Daphne mezereum). These researches may help in solving the problem of reproduction of other woody plants.

Abstract Daphne mezereum L. commonly known as February daphne or mezereon is a decorative shrub from the family Thymelaeaceae. It is a valuable nursery plant due to its high ornamental values, but its propagation by traditional methods is ineffective, therefore, little profitable. Micropropagation may be a good alternative way to produce this ornamental shrub. The experiment aimed to examine the effect of cytokinins (meta-Topolin, benzyladenine, and zeatin) and other growth regulators (gibberellic acid $\mathrm{GA}_{3}$ and auxin 1-naphthalene acetic acid NAA) added to the Murashige and Skoog (MS) and Woody Plant Medium (WPM) nutrients on regeneration of explants of D. mezereum 'Alba'. In the all treatments containing plant growth regulators (PGR), 100\% regeneration of explants has been observed. The highest number of shoots, after 6 weeks of culture, was produced on MS medium with $1 \mathrm{mg} \cdot \mathrm{L}^{-1} \mathrm{BA}$ and $0.1 \mathrm{mg} \cdot \mathrm{L}^{-1} \mathrm{NAA}$. The longest shoots were produced on MS medium with $0.1 \mathrm{mg} \cdot \mathrm{L}^{-1}$ of gibberellic acid $\left(\mathrm{GA}_{3}\right)$ and $1 \mathrm{mg} \cdot \mathrm{L}^{-1}$ of meta-Topolin $(\mathrm{mT})$. Generally, the type and concentration of plant growth regulators had an essential effect on regeneration and growth of shoots of Daphne mezereum 'Alba' in the in vitro culture.

Keywords Cytokinins $\cdot$ Gibberellin $\cdot$ Micropropagation $\cdot$ PGR $\cdot$ Woody plant

$\begin{array}{ll}\text { Abbreviations } \\ \text { mT } & \text { Meta-Topolin } \\ \text { BA } & \text { Benzyladenine } \\ \text { GA }_{3} & \text { Gibberellic acid } \\ \text { NAA } & \text { 1-Naphthalene acetic acid } \\ \text { MS } & \text { Murashige and Skoog (1962) medium } \\ \text { WPM } & \text { Woody plant medium (1980) } \\ \text { PGR } & \text { Plant growth regulator } \\ \text { TDZ } & \text { Thidiazuron } \\ \text { Zea } & \text { Zeatin }\end{array}$

Karolina Nowakowska

karolina_nowakowska@sggw.pl

Andrzej Pacholczak

andrzej_pacholczak@sggw.pl

1 Department of Ornamental Plants, Faculty of Horticulture, Biotechnology and Landscape Architecture, Warsaw University of Life Sciences (SGGW), 166 Nowoursynowska Str, 02-787 Warsaw, Poland

\section{Introduction}

February daphne Daphne mezereum L. belonging to the family Thymelaeaceae is legally protected in Poland. It needs to be preserved as its habitat, i.e., deciduous forests are being replaced by conifers, the shrub flowering branches are torn away and plants are dug out of natural stands and transferred into gardens (Piekos-Mirkowa and Mirek 2006). Apart from flowers which appear very early in spring plants produce ornamental red berries of $1 \mathrm{~cm}$ in diameter which ripen at the end of June. The shrub is mainly used in private gardens, on flower beds and in rock gardens. The cultivar 'Alba' with white flowers and yellow fruits is often produced in nurseries (PiekosMirkowa and Mirek 2006; Dirr 2009). February daphne is difficult to propagate: its stem cuttings root poorly even under optimal conditions, so this propagation method is not commercially used as it is inefficient. Other propagation methods of this valuable species are now being sought and one of the solutions may be tissue culture. According to Marks (1997), trials concentrate mainly on two species: D. $\times$ burkwoodii and D. odora, but due to the growing interest in other ornamental daphne species, the tissue 
cultures have been studied as well for: $D$. cneorum, $D$. laureola, D. mezereum, D. pontica, D. retusa and D. tangutica. Generally, the culture medium used for propagation of woody plants is WPM (Woody Plant Medium) which differs from the most popular MS (Murashige and Skoog) by a lower nitrogen content and a higher sulphur concentration (Murashige and Skoog 1962; Lloyd and McCown 1980).

Apart from the composition of macro- and microelements in a culture medium, the presence and concentration of the appropriate growth regulators are one of the important factors used to control growth and development of plants in tissue cultures. Auxins and cytokinins play a fundamental role in many aspects of plant development. Their interaction controls significant morphological processes, such as for example meristem appearance and development. During the stage of plant multiplication in vitro, the auxins are used in low concentrations, and accompanied by high concentrations of cytokinins which stimulate shoot proliferation (Su et al. 2011). Auxins have a broad spectrum of action in plants. Their most important effects in the in vitro cultures are enhancement of root and shoot production, stimulation of callus cell divisions, differentiation of conductive tissues, cell elongation, and inducing apical domination (Singh et al. 2016). This is confirmed by the results of research on the micropropagation of Althaea officinalis L. The optimum results of regeneration were observed on the MS medium with $(7.5 \mu \mathrm{M})$ BA and $(0.5 \mu \mathrm{M})$ NAA. On this combination, $95 \%$ explants regenerated, and on average, 26 shoots per explant was obtained (Naz et al. 2015).

The commonly used cytokinins in micropropagation are benzyladenine (BA) and meta-Topolin (mT). They are used during the stage of multiplication to obtain a maximum number of axillary shoots, i.e., new microcuttings. Contrary to auxins, they inhibit the root growth so they are not present in the culture media in the stage of rooting (Teixeira da Silva 2012). Recently, mT (meta-Topolin) has become the more common cytokinin in the in vitro plant production (Gentile et al. 2014; Koszeghi et al. 2014). Topolins are now alternative cytokinins for BA or TDZ (Thidiazuron) which have been most popular in micropropagation of many plants. Their application allows to avoid many problems such as poor regeneration, lower rooting ability resulting from a cytokinin application and dying of plants during acclimatization to the ex vitro conditions (Tarkowská et al. 2003; Aremu et al. 2012; Amoo and Van Staden 2013; Amoo et al. 2015). Zeatin is another cytokinin, often used during culture initiation because of a positive impact on shoot regeneration during the multiplication stage (Reed and Abdelnour 1991; Wang et al. 2002). Other important growth regulators are gibberellins. The most active and the most frequently used is gibberellic acid $\left(\mathrm{GA}_{3}\right)$ which stimulates internode elongation as well as differentiation of wood and cambium (Zhang et al. 2008).

The aim of this work was to determine the effect of selected growth regulators on the shoot regeneration in Daphne mezereum 'Alba' during micropropagation.

\section{Materials and methods}

The experiments were carried out in the laboratory of tissue cultures of the Dept. of Ornamental Plants at the Faculty of Horticulture, Biotechnology and Landscape Architecture of Warsaw University of Life Sciences (SGGW) in Warsaw. The cultivar 'Alba' of February mezereum (Daphne mezereum L.) was the experimental plant. The material for the initiation of cultures was young 5-8 $\mathrm{cm}$ fragments of shoots that came from 3-year-old mother shrubs from nursery. Before decontamination, they were divided into smaller fragments, and one- or two-node fragments of shoots were laid on the medium. The initial material used in the stage of multiplication was obtained from the 8-10-week-old in vitro cultures growing on the MS medium supplemented with $2.5 \mathrm{mg} \cdot \mathrm{L}^{-1} \mathrm{BA}$ and $0.1 \mathrm{mg} \cdot \mathrm{L}^{-1} \mathrm{NAA}$. The composition of culture media was prepared according to Murashige and Skoog (1962) and Lloyd and McCown (1980). Sucrose and myo-inositol were added to the medium as carbohydrate sources. Vitamins, macro- and micronutrients were added in a form of solutions prepared earlier and stored at $4{ }^{\circ} \mathrm{C}$ while the medium $\mathrm{pH}$ was adjusted to 5.7 with $\mathrm{HCl}$ and $\mathrm{NaOH}$. The solidifying factor was Bacto Agar. The medium was portioned $(50 \mathrm{ml})$ to 450 jars which were covered with transparent screw caps and subjected to autoclaving at $121^{\circ} \mathrm{C}$ and under pressure of $1.2 \mathrm{~kg} \cdot \mathrm{cm}^{-2}(110 \mathrm{kPa})$ for $20 \mathrm{~min}$.

\subsection{Type and concentration of selected cytokinins}

In the first experiment, the effect of cytokinin type and concentration on shoot regeneration in D. mezereum 'Alba' was evaluated. The following cytokinins were added to MS or WPM medium: meta-Topolin, zeatin and benzyladenine, each in concentration of $0,0.5,1,2$ and $3 \mathrm{mg} \mathrm{L}^{-1}$ (Table 1). Each treatment included 10 replicates with 6 explants (in total 60 explants per treatment).

\subsection{Addition of auxin and gibberellin}

In the second experiment, the effect of auxin or gibberellin presence in the culture medium was evaluated on shoot regeneration (Table 2). The plantlets were placed on MS or WPM with the following combinations of growth regulators. 
Table 1 Treatments in the first experiment: type and concentration of cytokinins

\begin{tabular}{lll}
\hline Type of medium & Cytokinin & $\begin{array}{l}\text { Cytokinin } \\
\text { concentration } \\
\left(\mathrm{mg} \cdot \mathrm{L}^{-1}\right)\end{array}$ \\
\hline MS/WPM & $\mathrm{mT}$ & 0 \\
& & 0.5 \\
& 1 \\
& & 2 \\
MS/WPM & BA & 3 \\
& & 0 \\
& & 0.5 \\
& & 1 \\
& & 2 \\
MS/WPM & 3 \\
& Zea & 0 \\
& & 0.5 \\
& & 1 \\
& & 2 \\
\hline
\end{tabular}

Table 2 Treatments in the second experiment: addition of auxin and gibberellin

\begin{tabular}{llll}
\hline Medium & $\begin{array}{l}\text { Growth regulators } \\
\text { added }\left(\mathrm{mg} \cdot \mathrm{L}^{-1}\right)\end{array}$ & Medium & $\begin{array}{l}\text { Growth } \\
\text { regulators added } \\
\left(\mathrm{mg} \cdot \mathrm{L}^{-1}\right)\end{array}$ \\
\hline MS & 0 & $\mathrm{MS}$ & 0 \\
& $0.1 \mathrm{NAA}$ & & $1 \mathrm{GA}_{3}$ \\
& $0.1 \mathrm{NAA}+1 \mathrm{BA}$ & & $1 \mathrm{GA}_{3}+0.1 \mathrm{NAA}$ \\
& $0.1 \mathrm{NAA}+1 \mathrm{mT}$ & & $1 \mathrm{GA}_{3}+1 \mathrm{mT}$ \\
& $0.1 \mathrm{NAA}+1 \mathrm{GA}_{3}$ & & $1 \mathrm{GA}_{3}+1 \mathrm{BA}$ \\
WPM & 0 & $\mathrm{WPM}$ & 0 \\
& $0.1 \mathrm{NAA}$ & & $1 \mathrm{GA}_{3}$ \\
& $0.1 \mathrm{NAA}+1 \mathrm{BA}$ & & $1 \mathrm{GA}_{3}+0.1 \mathrm{NAA}$ \\
& $0.1 \mathrm{NAA}+1 \mathrm{mT}$ & & $1 \mathrm{GA}_{3}+1 \mathrm{mT}$ \\
& $0.1 \mathrm{NAA}+1 \mathrm{GA}$ & & $1 \mathrm{GA}_{3}+1 \mathrm{BA}$ \\
\hline
\end{tabular}

\subsection{Collecting results and data analysis}

Three and 6 weeks after the culture initiation, the following parameters of the multiplication stage were evaluated: a percentage of regenerating explants, a number of shoots per explant and shoot length. The results were statistically evaluated and subjected to the one-way analysis of variance by the Statgraphics Plus 4.1. program. To compare the means, the Duncan's test was used at $\alpha=0.05$.

\section{Results}

\subsection{Type and concentration of selected cytokinins}

A one-way analysis of variance showed a highly significant effect of the nutrient composition on the regeneration of explants. The effect of type and concentration of selected CKs on shoot proliferation is presented in Table 3.

In both, after 3 and 6 weeks of culture, 100\% regeneration occurred in all the treatments besides MS 0. Only on this medium - devoid of growth regulators-the explants were dying during culture and on the second counting date, the percentage of dead explants reached $12 \%$ of the initial plantlet number.

The most abundant proliferation on the first counting date was observed on MS supplemented with $0.5-2 \mathrm{mg} \cdot \mathrm{L}^{-1} \mathrm{BA}$, or 0.5 and $1 \mathrm{mg} \cdot \mathrm{L}^{-1} \mathrm{Zea}$ as well as on WPM supplemented with $2 \mathrm{mg} \cdot \mathrm{L}^{-1} \mathrm{mT}$. The lowest number of new shoots (only 1.28-1.45 per explant) was produced by explants cultured on control media (0) without cytokinins (Fig. 1a) while on the best media approx. three times more shoots were obtained. In addition, during the second evaluation (after 6 weeks of culture), the lowest regeneration rate was found on explants cultured without cytokinins. The highest numbers of new shoots were produced on explants regenerating on MS in the presence of $0.5-2 \mathrm{mg} \cdot \mathrm{L}^{-1}$, $\mathrm{mT}$ in concentration $1 \mathrm{mg} \cdot \mathrm{L}^{-1}$, Zea $3 \mathrm{mg} \cdot \mathrm{L}^{-1}$ as well as on WPM supplemented with $2 \mathrm{mg} \cdot \mathrm{L}^{-1}$ $\mathrm{mT}$. According to the visual observations, the WPM composition is suitable for regeneration of $D$. mezereum 'Alba' during the long-term culture and only in combination with meta-Topolin. Plantlets from these treatments looked the best, i.e., they had well developed stems and leaves without any traces of mineral deficiency (Fig. 1b, c). Regeneration of new shoots was limited by a too high cytokinin concentration. After 3 weeks, it was evident on MS supplemented with Zea and $\mathrm{mT}$, where in treatments with the cytokinin concentrations $2 \mathrm{mg} \cdot \mathrm{L}^{-1}$ and more, the shoot number was decreasing. In addition, on WPM, the highest $\mathrm{mT}$ concentration resulted in a decreased shoot number relative to that obtained by the lower cytokinin concentrations. During the second evaluation date, the negative effect of the higher concentrations of BA and $\mathrm{mT}$ was also evident.

The longest shoots after 3 weeks of culture were produced on MS supplemented with $2 \mathrm{mg} \cdot \mathrm{L}^{-1} \mathrm{BA}$ and 1 or $3 \mathrm{mg} \cdot \mathrm{L}^{-1} \mathrm{Zea}$. At that moment, the shoot length means were uniform and the longest shoots differed from the shortest ones (obtained on WPM 0 ) only by $0.3 \mathrm{~cm}$. After successive 3 weeks, the medium MS 2 BA gave the best results and produced shoots approx. 3 times longer than those on WPM 0 . The negative effect of the higher BA 
Table 3 Effect of type and concentration of cytokinins on regeneration and growth of Daphne mezereum 'Alba' after 3 and 6 weeks of culture

\begin{tabular}{|c|c|c|c|c|c|c|c|c|}
\hline \multirow[t]{2}{*}{ Medium } & \multirow{2}{*}{$\begin{array}{l}\text { Type of } \\
\text { cytokinin }\end{array}$} & \multirow{2}{*}{$\begin{array}{l}\text { Growth regulators } \\
\text { added }\left(\mathrm{mg} \cdot \mathrm{L}^{-1}\right)\end{array}$} & \multicolumn{2}{|c|}{ Regeneration rate (\%) } & \multicolumn{2}{|l|}{ No. of shoots } & \multicolumn{2}{|c|}{ Shoot length $(\mathrm{cm})$} \\
\hline & & & After 3 weeks & After 6 weeks & After 3 weeks & After 6 weeks & After 3 weeks & After 6 weeks \\
\hline \multirow[t]{5}{*}{ MS } & \multirow[t]{10}{*}{$\mathrm{mT}$} & 0 & $93.2 \mathrm{a}^{*}$ & $88.4 a^{* *}$ & $1.28 \mathrm{a}$ & $1.33 \mathrm{a}$ & 0.66 fghi & $0.63 \mathrm{ab}$ \\
\hline & & 0.5 & $100 \mathrm{a}$ & $100 \mathrm{a}$ & $1.60 \mathrm{abc}$ & $4.18 \mathrm{~cd}$ & 0.68ghij & 0.92efgh \\
\hline & & 1 & $100 \mathrm{a}$ & $100 \mathrm{a}$ & 2.50defg & $7.08 \mathrm{i}$ & 0.63 defgh & $1.11 \mathrm{ij}$ \\
\hline & & 2 & $100 \mathrm{a}$ & $100 \mathrm{a}$ & $1.81 \mathrm{bc}$ & $4.03 \mathrm{~cd}$ & $0.55 \mathrm{abc}$ & $0.85 \mathrm{def}$ \\
\hline & & 3 & $100 \mathrm{a}$ & $100 \mathrm{a}$ & $2.10 \mathrm{~cd}$ & $3.17 \mathrm{~b}$ & $0.61 \mathrm{cdefg}$ & $0.71 b c$ \\
\hline \multirow[t]{5}{*}{ WPM } & & 0 & $100 \mathrm{a}$ & $100 \mathrm{a}$ & $1.41 \mathrm{ab}$ & $1.46 \mathrm{a}$ & $0.50 \mathrm{ab}$ & $0.51 \mathrm{a}$ \\
\hline & & 0.5 & $100 \mathrm{a}$ & $100 \mathrm{a}$ & 2.46def & $3.93 \mathrm{~cd}$ & $0.53 \mathrm{abc}$ & $0.80 \mathrm{cdef}$ \\
\hline & & 1 & $100 \mathrm{a}$ & $100 \mathrm{a}$ & $2.33 \mathrm{de}$ & $3.53 b c$ & $0.53 \mathrm{abc}$ & 0.79 cde \\
\hline & & 2 & $100 \mathrm{a}$ & $100 \mathrm{a}$ & $3.84 \mathrm{ij}$ & $5.39 \mathrm{fg}$ & $0.58 \mathrm{bcdef}$ & $0.84 \mathrm{cdef}$ \\
\hline & & 3 & $100 \mathrm{a}$ & $100 \mathrm{a}$ & $2.88 \mathrm{fgh}$ & $3.99 \mathrm{~cd}$ & $0.53 \mathrm{abc}$ & $0.75 \mathrm{bcd}$ \\
\hline \multirow[t]{5}{*}{ MS } & \multirow[t]{10}{*}{ BA } & 0 & $93.2 \mathrm{a}$ & $88.4 \mathrm{a}$ & $1.37 \mathrm{ab}$ & $1.43 \mathrm{a}$ & 0.69ghij & $0.78 \mathrm{~cd}$ \\
\hline & & 0.5 & $100 \mathrm{a}$ & $100 \mathrm{a}$ & $3.76 \mathrm{ij}$ & $6.22 \mathrm{~h}$ & $0.76 \mathrm{jkl}$ & $1.10 \mathrm{ij}$ \\
\hline & & 1 & $100 \mathrm{a}$ & $100 \mathrm{a}$ & $3.86 \mathrm{ij}$ & $5.84 \mathrm{gh}$ & $0.74 \mathrm{ijkl}$ & $1.31 \mathrm{k}$ \\
\hline & & 2 & $100 \mathrm{a}$ & $100 \mathrm{a}$ & $3.80 \mathrm{ij}$ & $6.09 \mathrm{gh}$ & $0.79 \mathrm{klm}$ & $1.65 \mathrm{~m}$ \\
\hline & & 3 & $100 \mathrm{a}$ & $100 \mathrm{a}$ & $2.90 \mathrm{fgh}$ & $4.22 \mathrm{~cd}$ & $0.56 \mathrm{abcde}$ & 0.99ghi \\
\hline \multirow[t]{5}{*}{ WPM } & & 0 & $100 \mathrm{a}$ & $100 \mathrm{a}$ & $1.45 \mathrm{ab}$ & $1.46 \mathrm{a}$ & $0.49 \mathrm{a}$ & $0.52 \mathrm{a}$ \\
\hline & & 0.5 & $100 \mathrm{a}$ & $100 \mathrm{a}$ & $2.68 \mathrm{efg}$ & $5.77 \mathrm{gh}$ & 0.68fghij & $0.74 \mathrm{bcd}$ \\
\hline & & 1 & $100 \mathrm{a}$ & $100 \mathrm{a}$ & 2.66efg & $4.58 \mathrm{de}$ & 0.65 efghi & 1.501 \\
\hline & & 2 & $100 \mathrm{a}$ & $100 \mathrm{a}$ & $2.55 \mathrm{defg}$ & $4.15 \mathrm{~cd}$ & 0.63 defgh & $1.17 \mathrm{j}$ \\
\hline & & 3 & $100 \mathrm{a}$ & $100 \mathrm{a}$ & $3.00 \mathrm{gh}$ & $4.49 \mathrm{de}$ & 0.65efghi & $0.71 b c$ \\
\hline \multirow[t]{5}{*}{ MS } & \multirow[t]{10}{*}{ Zea } & 0 & $93.2 \mathrm{a}$ & $88.4 \mathrm{a}$ & $1.36 \mathrm{ab}$ & $1.62 \mathrm{a}$ & $0.52 \mathrm{ab}$ & $0.71 b c$ \\
\hline & & 0.5 & $100 \mathrm{a}$ & $100 \mathrm{a}$ & $3.93 \mathrm{j}$ & $4.96 \mathrm{ef}$ & $0.71 \mathrm{hijk}$ & 0.92efgh \\
\hline & & 1 & $100 \mathrm{a}$ & $100 \mathrm{a}$ & $3.92 \mathrm{j}$ & $4.53 \mathrm{de}$ & $0.89 \mathrm{~m}$ & 0.91efgh \\
\hline & & 2 & $100 \mathrm{a}$ & $100 \mathrm{a}$ & $3.37 \mathrm{hi}$ & $5.47 \mathrm{fg}$ & 0.68ghij & $0.85 \mathrm{def}$ \\
\hline & & 3 & $100 \mathrm{a}$ & $100 \mathrm{a}$ & $2.67 \mathrm{efg}$ & $7.39 \mathrm{i}$ & $0.821 \mathrm{~m}$ & 1.02hij \\
\hline \multirow[t]{5}{*}{ WPM } & & 0 & $100 \mathrm{a}$ & $100 \mathrm{a}$ & $1.37 \mathrm{ab}$ & $1.38 \mathrm{a}$ & $0.52 \mathrm{ab}$ & $0.55 \mathrm{a}$ \\
\hline & & 0.5 & $100 \mathrm{a}$ & $100 \mathrm{a}$ & $2.84 \mathrm{efg}$ & $6.04 \mathrm{gh}$ & 0.64defgh & 0.92efgh \\
\hline & & 1 & $100 \mathrm{a}$ & $100 \mathrm{a}$ & 2.63efg & $5.55 \mathrm{fgh}$ & 0.64defgh & $0.92 \mathrm{efgh}$ \\
\hline & & 2 & $100 \mathrm{a}$ & $100 \mathrm{a}$ & 2.48def & $5.93 \mathrm{gh}$ & 0.63defgh & 0.93 fgh \\
\hline & & 3 & $100 \mathrm{a}$ & $100 \mathrm{a}$ & 2.39def & $5.67 \mathrm{fgh}$ & $0.61 \mathrm{cdefg}$ & 0.86defg \\
\hline
\end{tabular}

* Means in a column followed by the same letter do not differ significantly at $p=0.05$

**The data at particular term should be considered separated

(WPM) and $\mathrm{mT}$ (MS) concentrations on shoot elongation was confirmed: the shoots were shorter than those on the best media by $0.40 \mathrm{~cm}$ and $0.79 \mathrm{~cm}$, respectively, for MS supplemented with mT and WPM with BA.

\subsection{Addition of auxin and gibberellin}

The one-way analysis of variance showed the highly significant effect of medium composition on shoot regeneration (Table 4). In the case of the MS medium, this effect was seen when the naphthalene acetic acid (NAA) was used jointly with another growth regulator. During the first observation (after 3 weeks), the highest shoot number (6 per explant) was obtained on MS supplemented with NAA and BA. The shoot number doubled between the first and the second observation dates on following media: MS with NAA and BA, MS with NAA, and $\mathrm{mT}$ and WPM with NAA and BA.

The positive effect on shoot length was evident in MS supplemented with NAA and $\mathrm{GA}_{3}$ where shoots attained $1 \mathrm{~cm}$, being 35\% longer than on MS 0. Shoot length increased during culture in all the treatments except those without growth regulators. On the second date, the longest shoots were on WPM with NAA and $\mathrm{GA}_{3}$, being three times longer than on WPM 0 (Table 4).

Gibberellin addition to both media (WPM and MS) was favorable for regeneration and growth of shoots only in the presence of other growth regulators (Table 5). On MS, the best regeneration occurred on treatments with $\mathrm{GA}_{3}$ and 
Fig. 1 a The weakest regeneration of D. mezereum 'Alba' shoots on the MS 0 medium (6 weeks). b Regeneration of D. mezereum 'Alba' shoots on the WPM medium with 2 mTs (6 weeks). c The nutritional deficiencies seen on the leaves of regenerating shoots on the MS medium with 1 Zea (6 weeks). d Visibly elongating internodes on the WPM medium with $1 \mathrm{GA}_{3}(6$ weeks $)$
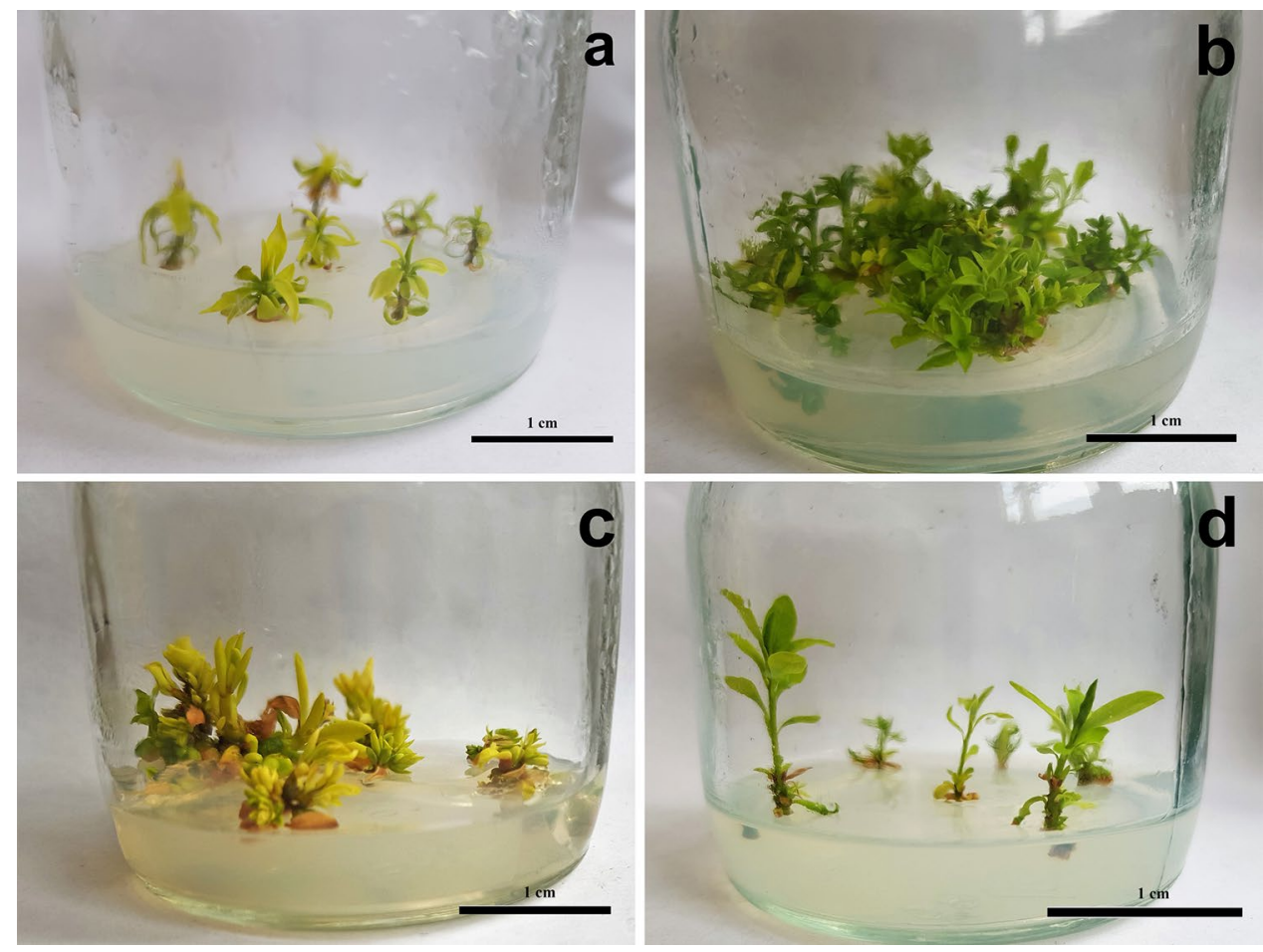

Table 4 The effect of auxin addition to MS and WPM medium

\begin{tabular}{|c|c|c|c|c|c|c|c|}
\hline \multirow[t]{2}{*}{ Type of medium } & \multirow{2}{*}{$\begin{array}{l}\text { Growth regulators } \\
\text { added }\left(\mathrm{mg} \cdot \mathrm{L}^{-1}\right)\end{array}$} & \multicolumn{2}{|c|}{ Regeneration rate $(\%)$} & \multicolumn{2}{|l|}{ No. of shoots } & \multicolumn{2}{|c|}{ Shoot length $(\mathrm{cm})$} \\
\hline & & After 3 weeks & After 6 weeks & After 3 weeks & After 6 weeks & After 3 weeks & After 6 weeks \\
\hline \multirow[t]{5}{*}{ MS } & 0 & $93.2 \mathrm{a}^{*}$ & $88.4 \mathrm{a}^{* *}$ & $1.5 \mathrm{a}$ & $1.6 \mathrm{a}$ & $0.71 \mathrm{~cd}$ & $0.71 \mathrm{~b}$ \\
\hline & $0.1 \mathrm{NAA}$ & $100 \mathrm{a}$ & $100 \mathrm{a}$ & $1.6 \mathrm{a}$ & $1.7 \mathrm{a}$ & $0.57 \mathrm{ab}$ & $0.74 b$ \\
\hline & $0.1 \mathrm{NAA}+1 \mathrm{BA}$ & $100 \mathrm{a}$ & $100 \mathrm{a}$ & $6.0 \mathrm{~d}$ & $11.6 \mathrm{f}$ & $0.75 \mathrm{~d}$ & $1.03 \mathrm{~cd}$ \\
\hline & $0.1 \mathrm{NAA}+1 \mathrm{mT}$ & $100 \mathrm{a}$ & $100 \mathrm{a}$ & $2.5 \mathrm{~b}$ & $5.4 \mathrm{~d}$ & $0.55 \mathrm{ab}$ & $0.85 \mathrm{de}$ \\
\hline & $0.1 \mathrm{NAA}+1 \mathrm{GA}_{3}$ & $100 \mathrm{a}$ & $100 \mathrm{a}$ & $2.6 \mathrm{~b}$ & $3.1 b$ & $0.97 \mathrm{f}$ & $1.21 \mathrm{e}$ \\
\hline \multirow[t]{5}{*}{ WPM } & 0 & $100 \mathrm{a}$ & $100 \mathrm{a}$ & $1.4 \mathrm{a}$ & $1.4 \mathrm{a}$ & $0.50 \mathrm{a}$ & $0.50 \mathrm{a}$ \\
\hline & $0.1 \mathrm{NAA}$ & $100 \mathrm{a}$ & $100 \mathrm{a}$ & $5.0 \mathrm{c}$ & $6.5 \mathrm{e}$ & $0.83 \mathrm{e}$ & $1.15 \mathrm{de}$ \\
\hline & $0.1 \mathrm{NAA}+1 \mathrm{BA}$ & $100 \mathrm{a}$ & $100 \mathrm{a}$ & $2.7 \mathrm{~b}$ & $5.6 \mathrm{~d}$ & $0.78 \mathrm{de}$ & $1.01 \mathrm{~cd}$ \\
\hline & $0.1 \mathrm{NAA}+1 \mathrm{mT}$ & $100 \mathrm{a}$ & $100 \mathrm{a}$ & $2.4 \mathrm{~b}$ & $4.2 \mathrm{c}$ & $0.64 b c$ & $0.98 \mathrm{c}$ \\
\hline & $0.1 \mathrm{NAA}+1 \mathrm{GA}_{3}$ & $100 \mathrm{a}$ & $100 \mathrm{a}$ & $5.2 \mathrm{c}$ & $5.6 \mathrm{~d}$ & $1.09 \mathrm{~g}$ & $1.48 \mathrm{f}$ \\
\hline
\end{tabular}

*Means in a column followed by the same letter do not differ significantly at $p=0.05$

**The data at particular term should be considered separated

NAA or $\mathrm{GA}_{3}$ and $\mathrm{mT}$. After 6 weeks of culture supplementation with gibberellin and meta-Topolin resulted in the highest regeneration rate-almost 6 shoots per explant. On WPM, on both observation dates, the best regeneration resulted from addition of $\mathrm{GA}_{3}$ and NAA. Supplementation of WPM with $\mathrm{GA}_{3}$ and $\mathrm{mT}$ gave a low regeneration rate on the first date but after 6 weeks, the result was 5 shoots per explant, similarly as in the treatment with gibberellin and auxin. Generally, the best regeneration at the beginning of the experiment was observed in explants on WPM with $\mathrm{GA}_{3}$ and NAA, while later this treatment and that on
MS supplemented with $\mathrm{GA}_{3}$ and $\mathrm{mT}$ produced 5 shoots per explant.

In treatments where MS was used together with growth regulators, the shoots were longer than in the control treatment MS 0. Both, after 3 and 6 weeks, the longest shoots were on MS with $\mathrm{GA}_{3}$ and $\mathrm{mT}$, being $0.3 \mathrm{~cm}$ and nearly $1.0 \mathrm{~cm}$ longer, respectively, than on MS 0. On WPM, growth regulators increased shoot length relative to WPM 0 in all the treatments, except when gibberellin was used alone. The longest shoots were on WPM with $\mathrm{GA}_{3}$ and NAA (Fig. 1d), where they attained $1.08 \mathrm{~cm}$ on the average. The increase in 
Table 5 The effect of gibberellin addition to MS and WPM medium

\begin{tabular}{|c|c|c|c|c|c|c|c|}
\hline \multirow[t]{2}{*}{ Type of medium } & \multirow{2}{*}{$\begin{array}{l}\text { Growth regulators } \\
\text { added }\left(\mathrm{mg} \cdot \mathrm{L}^{-1}\right)\end{array}$} & \multicolumn{2}{|c|}{ Regeneration rate $(\%)$} & \multicolumn{2}{|l|}{ No. of shoots } & \multicolumn{2}{|c|}{ Shoot length $(\mathrm{cm})$} \\
\hline & & After 3 weeks & After 6 weeks & After 3 weeks & After 6 weeks & After 3 weeks & After 6 weeks \\
\hline \multirow[t]{5}{*}{ MS } & 0 & $93.2 \mathrm{a}^{*}$ & $88.4 a^{* *}$ & $1.4 \mathrm{a}$ & $1.7 \mathrm{a}$ & $0.71 b$ & $0.72 \mathrm{a}$ \\
\hline & $1 \mathrm{GA}_{3}$ & $100 \mathrm{a}$ & $100 \mathrm{a}$ & $1.6 \mathrm{ab}$ & $1.6 \mathrm{a}$ & $0.89 \mathrm{~cd}$ & $1.07 \mathrm{~cd}$ \\
\hline & $1 \mathrm{GA}_{3}+0.1 \mathrm{NAA}$ & $100 \mathrm{a}$ & $100 \mathrm{a}$ & $2.7 \mathrm{c}$ & $2.9 \mathrm{~b}$ & $0.96 \mathrm{de}$ & $1.29 \mathrm{e}$ \\
\hline & $1 \mathrm{GA}_{3}+1 \mathrm{mT}$ & $100 \mathrm{a}$ & $100 \mathrm{a}$ & $2.9 \mathrm{c}$ & $5.8 \mathrm{e}$ & $1.04 \mathrm{ef}$ & $1.68 \mathrm{~g}$ \\
\hline & $1 \mathrm{GA}_{3}+1 \mathrm{BA}$ & $100 \mathrm{a}$ & $100 \mathrm{a}$ & $1.9 \mathrm{~b}$ & $4.2 \mathrm{c}$ & $0.75 b$ & $0.98 \mathrm{c}$ \\
\hline \multirow[t]{5}{*}{ WPM } & 0 & $100 \mathrm{a}$ & $100 \mathrm{a}$ & $1.4 \mathrm{a}$ & $1.4 \mathrm{a}$ & $0.75 b$ & $0.98 \mathrm{c}$ \\
\hline & $1 \mathrm{GA}_{3}$ & $100 \mathrm{a}$ & $100 \mathrm{a}$ & $1.5 \mathrm{ab}$ & $1.6 \mathrm{a}$ & $0.53 \mathrm{a}$ & $0.74 \mathrm{ab}$ \\
\hline & $1 \mathrm{GA}_{3}+0.1 \mathrm{NAA}$ & $100 \mathrm{a}$ & $100 \mathrm{a}$ & $5.1 \mathrm{~d}$ & $5.4 \mathrm{de}$ & $1.08 \mathrm{f}$ & $1.50 \mathrm{f}$ \\
\hline & $1 \mathrm{GA}_{3}+1 \mathrm{mT}$ & $100 \mathrm{a}$ & $100 \mathrm{a}$ & $3.0 \mathrm{c}$ & $4.9 \mathrm{~d}$ & $0.79 b c$ & $1.17 \mathrm{de}$ \\
\hline & $1 \mathrm{GA}_{3}+1 \mathrm{BA}$ & $100 \mathrm{a}$ & $100 \mathrm{a}$ & $1.3 \mathrm{a}$ & $4.2 \mathrm{c}$ & $0.71 b$ & $0.71 \mathrm{a}$ \\
\hline
\end{tabular}

*Means in a column followed by the same letter do not differ significantly at $p=0.05$

**The data at particular term should be considered separated

shoot length relative to the control medium without growth regulators occurred in all the treatments except that with $\mathrm{GA}_{3}$ and $\mathrm{BA}$.

\section{Discussion}

February daphne (Daphne mezereum L.) is an ornamental shrub legally protected in Poland in its natural habitats. Its cuttings root difficultly and shoots regenerate poorly when cut or damaged and plants lack an ability to branch, therefore, a suitable method to propagate the species needs to be developed. One of the solutions may be tissue cultures. The experiments described here concentrated on one of the micropropagation stages, i.e., the multiplication process. Three parameters showing the efficiency of propagation have been evaluated: the percentage of regenerating explants, the average number of shoots per explant and the mean shoot length.

A culture medium composition is one of the most important aspects during propagation, being fundamental for proper morphogenesis and propagation rate of a given taxon. During last several dozen years, numerous media have been elaborated for different plant groups or even species. The most often used is that developed by Murashige and Skoog (MS) (1962) which is regarded as a universal medium for most herbaceous plants. As compared to other media, it has a high ion concentration, especially that of nitrogen, potassium, zinc and chlorine (Leifert et al. 1995). For woody plants, usually the more diluted media are used such as Woody Plant Medium (WPM) with lower concentrations of nitrogen and potassium salts (Lloyd and McCown 1980). These experiments proved that the WPM composition is suitable for shoot regeneration in D. mezereum 'Alba', especially in the long-term cultures. Shoots were intensively green, without any leaf discolorations and both stems and leaves were well formed. In turn, on MS, without growth regulators plantlets were dying, especially at the end of culture, probably due to senescence processes. Such a phenomenon did not occur in plantlets on WPM, probably due to a lower content of macroelements resulting in a slower maturing and aging of explants.

The smallest numbers of new shoots were obtained from explants regenerating on control media without growth regulators (0). This could be expected as PGR control plant growth and development and their content in a multiplication medium is fundamental for an effective culture growth. Two basic groups of PGR are used in tissue cultures: auxins and cytokinins (Shahzad et al. 2017). Cytokinins are responsible for stimulation of cell divisions, initiate bud growth and proliferation (Van Staden et al. 2008). The cytokinin commonly used in the phase of multiplication is benzyladenine (BA) (Teixeira da Silva 2012). The percentage of daphne explant regeneration on media containing BA was $100 \%$. In fact, such good results were obtained in all the treatments, except in those on MS without growth regulators. Similar results were reported by Eng et al. (2015) who were propagating Citrus hystrix and Rasheed (2013) on Cestrum nocturnum. Supplementing $1.5 \mathrm{mg} \cdot \mathrm{L}^{-1} \mathrm{BA}$ to one of the treatments increased the percentage of regenerating explants from $40 \%$ without cytokinin to $100 \%$. Kulpa and Kubus (2010) studied the effect of MS and WPM media enriched with different cytokinins on shoot regeneration in Calycanthus fertilis. Shoot proliferation on WPM with BA was better than in the control medium without growth regulator. Enrichment of the medium with 0.5 and $1 \mathrm{mg} \cdot \mathrm{L}^{-1} \mathrm{BA}$ resulted in the increased shoot number per explant. However, using $2.5 \mathrm{mg} \cdot \mathrm{L}^{-1} \mathrm{BA}$ did not improve regeneration and decreased shoot length. Similar tendency was observed in these experiments on February daphne. In most cases, the 
too high cytokinin concentrations decreased regeneration, for example after 3 weeks of culture on MS supplemented with Zea or mT. Similarly, too high cytokinin concentration negatively affected shoot length: BA on WPM and $\mathrm{mT}$ on MS decreased shoot elongation. The similar results were obtained by Ahmad et al. (2013). After application of higher concentrations $(10$ or $20 \mu \mathrm{M})$ of the selected cytokines: $2 \mathrm{iP}$ and TDZ, during the regeneration of $\mathrm{Cya}$ mopsis tetragonoloba, obtained a less number of shoots and they were shorter compared to optimal concentrations.

Meta-Topolin is often used as BA replacement, because of the easier rooting of regenerants after its application (Werbrouck et al. 1996). Koszeghi et al. (2014) compared the effects of meta-Topolin and benzyladenine on regeneration of Oicimum basilicum cultured on MS. Among five mT concentrations tested the range between 0.25 and $1 \mathrm{mg} \cdot \mathrm{L}^{-1}$ produced the highest shoot number and a further increase in concentration was ineffective. Similar results were obtained here with February daphne. After 6 weeks of culture, the highest shoot number was obtained on MS with $1 \mathrm{mg} \cdot \mathrm{L}^{-1}$ meta-Topolin where shoots were also the longest. On WPM, the best proliferation occurred in presence of $2 \mathrm{mg} \cdot \mathrm{L}^{-1} \mathrm{mT}$.

Zeatin is another cytokinin often used in the stage of culture initiation though it also positively affects shoot regeneration in the multiplication stage (Wang et al. 2002). Thomson and Deering (2011) used zeatin in concentrations between 1.5 and $10 \mathrm{mg} \cdot \mathrm{L}^{-1}$ while propagating hazelnut. Plantlets treated with the lowest zeatin concentration produced 0.2 shoot per explant while with the increased cytokinin concentration, this result reached the value of 1.0 and 1.1: the fivefold increase in proliferation efficiency occurred due to the increased zeatin concentration-in the range from the lowest to the average. However, further doubling of the cytokinin content was inefficient. A similar tendency was seen in the present experiments where on MS medium supplemented with $1-3 \mathrm{mg} \cdot \mathrm{L}^{-1}$ zeatin a gradual increase in shoot proliferation occurred, reaching 7 shoots per explant after 6 weeks of culture. Good proliferation was also observed on WPM where regardless of the zeatin concentration 6 shoots on the average were produced per explant. Hanus-Fajerska et al. (2012) studied micropropagation of three Daphne species. On MS medium supplemented with $1 \mathrm{mg} \cdot \mathrm{L}^{-1} 2$-isopentyladenine and $0.1 \mathrm{mg} \cdot \mathrm{L}^{-1} 1$-naphthalene acetic acid, only 1.5 and 2.8 shoots per explant were produced in D. caucasica and D. jasminea, respectively. Here, in February daphne, shoot proliferation on explants cultured on comparable media was more abundant. Such a good result relative to other daphne species may be an indicator of a high regeneration potential of $D$. mezereum in vitro.

The successive experiments aimed to evaluate the effect of a joint supplementation of culture media with cytokinin, auxin and gibberellic acid.
Generally, benzyladenine is used during micropropagation of woody plants. It may be applied singly or together with NAA (Kobayashi et al. 2003; Costa et al. 2004; Zou et al. 2008). These two growth regulators have long been regarded as essential for plant growth and development. Cytokinins in high concentration with low contents of auxins affect cell divisions and are responsible for the in vitro regeneration (Fatima et al. 2011). During multiplication stage NAA is added in low concentrations, together with a cytokinin. This principle was confirmed in these experiments on February daphne. A positive effect was observed on MS medium supplemented with NAA and another growth regulator. During the first evaluation, the highest shoot number (6 per explant) was obtained on MS with NAA and BA and this combination was the best multiplication medium for D. mezereum 'Alba'. A twofold increase in shoot number was observed on media where NAA was used jointly with BA or mT. A similar mutual enhancement of the effects exerted by growth regulators was reported by Yusuf et al. (2011) who studied the effects of benzylenine and 1-naphthalene acetic acid on regeneration in Chinese ginger (Boesenbergia rotunda). The best multiplication was obtained on the medium with $2 \mathrm{mg} \cdot \mathrm{L}^{-1} \mathrm{BA}$ and $0.5 \mathrm{mg} \cdot \mathrm{L}^{-1} \mathrm{NAA}$ while the higher auxin concentrations lowered shoot proliferation, probably due to inducing apical dominance. During shoot induction of Dianthus caryophyllus L. in in vitro culture, Lukatkin et al. (2017) showed that the combination of $8.9 \mu \mathrm{M}$ BA and $2.9 \mu \mathrm{M}$ IAA improved the number of shoots/ explants obtained, their length and the number of internodes/ shoots.

Similarly as other PGR, gibberellins play an important role in plant development. For example during seed germination, shoot elongation, or inducing of flowering (Yamaguchi 2008). Their ability to stimulate cell growth and elongation may be used to stimulate growth of microshoots of woody plants before the stage of rooting. Sometimes $\mathrm{GA}_{3}$ is added to a medium to stimulate callus development or to overcome dwarfness of microcuttings (Kumar et al. 2008). In February daphne, $\mathrm{GA}_{3}$ together with another PGR increased a mean shoot length as compared to control treatments (without PGR). Using $\mathrm{GA}_{3}$ with meta-Topolin resulted in shoots $1.2 \mathrm{~cm}$ long, i.e., longer than in the treatments where both growth regulators were used separately. A similar synergistic effect of these growth regulators was observed by Hiti Bandaralage et al. (2015) in their studies on regeneration in Persea americana Mill. Somayeh et al. (2011) showed that in Rosa pulverulenta cultured on MS with BA in the concentration range $0-1.8 \mathrm{mg} \cdot \mathrm{L}^{-1}$, addition of $1 \mathrm{mg} \cdot \mathrm{L}^{-1}$ of gibberellic acid resulted in the increased number and length of shoots. Here, the opposite tendency was observed. Both, on MS and WPM supplemented with $1 \mathrm{mg} \cdot \mathrm{L}^{-1}$ of BA and $\mathrm{GA}_{3}$, the explants regenerated less shoots than in the 
treatment with BA alone. Also, the shoot length measured after 6 weeks of culture was smaller on media with $\mathrm{GA}_{3}$.

\section{Conclusions}

These experiments allowed evaluating the effects of type and concentrations of selected growth regulators on one of the micropropagation stages, i.e., multiplication. Double evaluation-after 3 and 6 weeks of culture-allowed for an exact verification of multiplication efficiency by measuring the following parameters: rate of increase in percentage of regenerating explants, an average number of shoots per explant and shoot length attained during 6 weeks of culture. The best proliferation occurred on MS media supplemented with BA and NAA but WPM enriched with mT gave shoots of better quality, i.e., more vividly colored. Synergistic action of auxins and cytokinins and gibberellic acid was evident: a joint application of different PGR gave better results than when the growth regulators were used singly. Such good results in the multiplication stage of $D$. mezereum 'Alba' may indicate a high regeneration potential of this species in tissue cultures. More studies are needed to develop a complete protocol of micropropagation of this valuable species which cannot be propagated effectively by conventional methods.

\section{Compliance with ethical standards}

Conflict of interest The authors declare that they have no conflict of interest. The research was financed only from the internal resources of the Department intended for research as part of the doctoral thesis.

Open Access This article is distributed under the terms of the Creative Commons Attribution 4.0 International License (http://creativeco mmons.org/licenses/by/4.0/), which permits unrestricted use, distribution, and reproduction in any medium, provided you give appropriate credit to the original author(s) and the source, provide a link to the Creative Commons license, and indicate if changes were made.

\section{References}

Ahmad N, Faisal M, Anis M (2013) Role of PGR on in vitro shoot propagation in Cyamopsis tetragonoloba L. (Taub.): a drought tolerant grain legume. Ren Fis Acc Lincei 24:7-12

Amoo SO, Van Staden J (2013) Influence of plant growth regulators on shoot proliferation and secondary metabolite production in micropropagated Huernia hystrix. Plant Cell Tissue Org Cult 112:249-256

Amoo SO, Aremu AO, Moyo M, Sunmonu TO, Plíhalová L, Doležal K, Van Staden J (2015) Physiological and biochemical effects of a tetrahydropyranyl-substituted meta-topolin in micropropagated Merwilla plumbea. Plant Cell Tissue Org Cult 121:579-590
Aremu AO, Bairu MW, Dolezal K, Finnie JF, Van Staden J (2012) Topolins: a panacea to plant tissue culture challenges? Plant Cell Tissue Org Cult 108:1-16

Costa MGC, Alves VS, Lani ERG, Mosquima PR, Carvalho CR, Otoni WC (2004) Morphogenic gradients of adventitious bud and shoot regeneration in epicotyl explants of Citrus. Sci Hortic 100:63-74

Dirr MA (2009) Manual of woody landscape plants, 6th edn. Stipes Publishing LLC, Champaign, p 1325

Eng W, Aziz H, Sinniah M (2015) In vitro regeneration of Citrus hystrix DC. Br J Bot 38(2):235-242

Fatima N, Ahmad N, Anis M (2011) Enhanced in vitro regeneration and change in photosynthetic pigments, biomass and proline content in Withania somnifera L. (Dunal) induced by copper and zinc ions. Plant Physiol Biochem 49:1465-1471

Gentile A, Gutiérrez MJ, Martinez J, Frattarelli A, Nota P, Caboni E (2014) Effect of meta-Topolin on micropropagation and adventitious shoot regeneration in Prunus rootstocks. Plant Cell Tissue Org 118:373-381

Hanus-Fajerska E, Wiszniewska A, Czaicki P (2012) Effectiveness of Daphne L (Thymelaeaceae) in vitro propagation, rooting of microshoots and acclimatization of plants. Acta Agrobot 65(1):21-28

Hiti Bandaralage JCA, Hayward A, O’Brien C, Mitter N (2015) Gibberellin and cytokinins in synergy for a rapid nodal multiplication system of avocado. VIII World Avocado Congress, Lima, Peru, pp 95-98

Kobayashi AK, Bespalhok JC, Pereira LFP, Vieira LGE (2003) Plant regeneration of sweet orange (Citrus sinensis) from thin sections of mature stem segments. Plant Cell Tissue Org Cult 74:99-102

Koszeghi S, Bereczki C, Balog A, Benedek K (2014) Comparing the effects of benzyladenine and meta-Topolin on sweet basil (Ocimum basilicum) micropropagation. Not Sci Biol 6:422-426

Kulpa D, Kubus M (2010) Micropropagation of Calycanthus fertilis. Dendrobiology 64:31-35

Kumar S, Chandra A, Gupta MG (2008) Plantlet regeneration via multiple shoot induction in Indian accessions of lucerne (Medicago sativa L.). J Plant Biochem Biot 17:181-184

Leifert C, Murphy KP, Lumsden PJ (1995) Mineral and carbohydrate nutrition of plant cell and tissue cultures. Crit Rev Plant Sci 14(2):83-109

Lloyd G, McCown BH (1980) Commercially-feasible micropropagation of mountain laurel, Kalmia latifolia by use of shoot-tip culture. Comb Proc Int Plant Propag Soc 30:421-427

Lukatkin AS, Mokshin EV, Teixeira da Silva JA (2017) Use of alternative plant growth regulators and carbon sources to manipulate Dianthus caryophyllus L. shoot induction in vitro. Rend Fis Acc Lincei 28:583-588

Marks TR (1997) Micropropagation of Daphne. In: Bajaj YPS (ed) High-tech and micropropagation VI. Springer, Berlin, pp 113-130

Murashige T, Skoog F (1962) A revised medium for rapid growth and bio assays with tobacco tissue cultures. Physiol Plant 15:473-497

Naz R, Anis M, Aref IM (2015) Management of cytokinin-auxin interactions for in vitro shoot proliferation of Althaea officinalis L.: a valuable medicinal plant. Rend Fis Acc Lincei 26:323-334

Piękoś-Mirkowa H, Mirek Z (2006) Flora Polski. Rośliny Chronione [Polish Flora. Protected Plants]. MULTICO, Warszawa

Rasheed KA (2013) Improving an in vitro propagation protocol for Cestrum nocturnum L. Acta Agrobot 66(2):35-44

Reed BM, Abdelnour EA (1991) The use of zeatin to initiate in vitro cultures of Vaccinium species and cultivars. HortSci A Publ Am Soc Horticult Sci 26(10):1320-1322

Shahzad A et al (2017) Historical perspective and basic principles of plant tissue culture. In: Abdin M, Kiran U, Kamaluddin M, Ali A (eds) Plant biotechnology: principles and applications. Springer, Singapore, pp 1-36 
Singh R, Kumar S, Kalia S, Sharma SK, Kalia RK (2016) Recent advances in understanding the role of growth regulators in plant growth and development in vitro-III. Inhibitors of growth regulators. Indian For 142(11):1065-1072

Somayeh K, Maryam JK, Ali H, Pegah K, Mohamad RA (2011) Micropropagation and medium-term conservation of Rosa pulverulenta. Acta Sci Agron 33(2):297-301

Su YH, Liu YB, Zhang XS (2011) Auxin-cytokinin interaction regulates meristem development. Mol Plant 4:616-625

Tarkowská D, Doležal K, Tarkowski P, Ástot C, Holub J, Fuksová K, Schmülling T, Sandberg G, Strnad M (2003) Identification of new aromatic cytokinins in Arabidopsis thaliana and Populus $x$ canadensis leaves by LC-(+)ESI-MS and capillary liquid chromatography/frit-fast atom bombardment mass spectrometry. Physiol Plant 117:579-590

Teixeira da Silva JA (2012) Is BA (6-benzyladenine) BAP (6-benzylaminopurine)? Asian Aust J Plant Sci Biotechnol 6(1):121-124

Thomson G, Deering T (2011) Effect of cytokinin type and concentration on in vitro shoot proliferation of hazelnut (Corylus avellana L.). N Z J Crop Hortic Sci 39(3):209-213

Van Staden J, Zazimalova E, George EF (2008) Plant growth regulators II: cytokinins, their analogues and antagonists. In: George EF, Hall MA, De Klerk GJ (eds) Plant propagation by tissue culture, vol. I the background, 3rd edn. Springer, Dordrecht, pp 205-226
Wang GY, Yuan MF, Hong Y (2002) In vitro flower induction in roses. In Vitro Cell Dev Biol Plant 38(5):513-518

Werbrouck SPO, Strnad M, Van Onckelen HA, Debergh PC (1996) Meta-topolin, an alternative to benzyladenine in tissue culture? Physiol Plant 98:291-297

Yamaguchi S (2008) Gibberellin metabolism and its regulation. Ann Rev Plant Biol 59:25-251

Yusuf N, Annuar M, Khalid N (2011) Rapid micropropagation of Boesenbergia rotunda (L.) Mansf. Kulturpfl. (a valuable medicinal plant) from shoot bud explants. Afr J Biotechnol 10(7):1194-1199

Zhang X, Wu Z, Huang C (2008) Effects of gibberellin mutations on in vitro shoot bud regeneration of Arabidopsis. Afr J Biotechnol 7(22):4159-4163

Zou X, Li D, Luo X, Luo K, Pei Y (2008) An improved procedure for Agrobacterium-mediated transformation of trifoliate orange (Poncirus trifoliata L. Raf.) via indirect organogenesis. In Vitro Cell Dev Plant 44(3):169-177

Publisher's Note Springer Nature remains neutral with regard to jurisdictional claims in published maps and institutional affiliations. 